\title{
An Assessment of Lebanese Companies' Motivators to Adopt CSR Strategies
}

\author{
Ghada M. Chehimi ${ }^{1}$, Ale J. Hejase ${ }^{2 *}$, Nour H. Hejase ${ }^{3}$ \\ ${ }^{1}$ Faculty of Letters, Lebanese University, Beirut, Lebanon \\ ${ }^{2}$ School of Business, Lebanese American University, Beirut, Lebanon \\ ${ }^{3}$ Freelance Researcher, Beirut, Lebanon \\ Email: *ale.hejase@lau.edu.lb
}

How to cite this paper: Chehimi, G.M., Hejase, A.J. and Hejase, N.H. (2019) An Assessment of Lebanese Companies' Motivators to Adopt CSR Strategies. Open Journal of Business and Management, 7, 1891-1925.

https://doi.org/10.4236/ojbm.2019.74130

Received: September 6, 2019

Accepted: October 9, 2019

Published: October 12, 2019

Copyright $\odot 2019$ by author(s) and Scientific Research Publishing Inc. This work is licensed under the Creative Commons Attribution International License (CC BY 4.0).

http://creativecommons.org/licenses/by/4.0/

\begin{abstract}
Corporate Social Responsibility (CSR) and its importance in companies around the globe have grown substantially in the past years. With the advent of globalization, managers in different contexts have been exposed to the notion of CSR and are being pressured to adopt CSR initiatives. This made organizations develop strategies to enhance managing their ways of working in a way that they can produce an overall positive impact on the surrounding environment. CSR helps the organization succeed in balancing its business goals and its impact on the environment. It is becoming vital for organizations to adopt environment-friendly ways of working, which not only lessens their negative impacts but also gives back to the community in general. However, despite CSR being a very significant issue, Lebanese companies, organizations and service industries are not quite embracing it as a fundamental part of their business plan. Failing to realize the authentic significance of CSR in the community and the low awareness levels about the topic will eventually have negative results on the companies themselves. Moreover, CSR is still a not well-comprehended term in Lebanese society as its benefits are vague and unclear. This research is an exploratory and quantitative study using a survey questionnaire distributed to a convenient sample of Lebanese managers and employees working in 5 different service industries in Lebanon. The purpose is to assess what motivates companies in Lebanon to adopt CSR strategies. Accordingly, the research also seeks to highlight people's awareness about CSR which in turn forces these companies to engage in CSR activities that will lead to a win-win situation. The outcomes may serve as eye openers and may shed light on important facts to be considered for further research or policy planning.
\end{abstract}

\section{Keywords}

CSR Strategy, Motivators, CSR Triple Bottom-Line, Sustainability, Lebanon 


\section{Introduction}

In today's economic and social environment, issues related to social responsibility and sustainability are gaining more and more importance, especially in the business sector ([1] [2] [3] [4]). Business goals and current operations are inseparable from the societies and environments within which they operate. Organizations have to account for the long-term impacts to support the sustainability of their businesses. "Whilst short-term economic gain can be pursued, the failure to account for longer-term social and environmental impacts makes those business practices unsustainable" [5] (p. 46). The broadest definition of CSR is concerned with what or should be the relationship between global corporations, governments of countries and individual citizens [6]. More locally the definition is concerned with the relationship between a corporate and the local society in which it resides or operates [7]. Another definition is concerned with the relationship between corporation and its stakeholders ([4] [8]). According to the EU Commission (2002) [9], “... CSR is a concept whereby companies integrate social and environmental concerns in their business operations and in their interaction with their stakeholders on a voluntary basis" (p. 3). Adopting CSR considers how a company can use this impact in a positive way, leading to sustainable growth and financial gains. Over the years, CSR has become more and more popular; back in 2007 more than $80 \%$ of the FTSE 100 index reported on Corporate Social Responsibility within their Annual Report.

All these definitions are pertinent and each represents a dimension of the issue. A parallel debate is taking place in the arena of ethics where the following question is raised; should corporations be controlled through increased regulation? ... will the ethical base of citizenship ensure socially responsible behavior and place it before cost and needs? However, this debate is taken seriously and concerns are resolved with some sort of social contract between corporations and society.

In short and to define and explain CSR, researchers had applied different methodological approaches: Some were summarizing existing definitions ([10] [11] [12] [13]), others were conducting interviews ([14] [15]), analyzing research papers ([16] [17] [18]), or dealing with the development of a CSR definition through theoretical reasoning ([19] [20] [21] [22]). The following common characteristics can be seen as a list of key elements that are most commonly used:

- CSR is the liability of business to act in accordance with the overall goals of society, and is therefore linked to sustainable development as a guiding vision.

- CSR depends on the political, institutional, and cultural context and environment, as it is dependent on the relationship between business and society.

- CSR is beyond compliance: being compliant to laws or regulation are prerequisites of responsible corporate behavior.

- CSR is voluntary (otherwise it would be part of compliance), but it is still perceived as a moral, ethical, or philanthropic obligation of business. How- 
ever, many NGOs and labor unions tend to question the idea of CSR as a voluntary concept.

- Making profits out of CSR: There is a lengthy debate on whether corporate measures that lead to profit can be perceived as CSR (e.g. "is it moral to make money out of being moral?") or-the other way round-if measures which do not lead to indirect profit at all, might be categorized as CSR (i.e. if philanthropy is part of CSR or not).

Summarizing these elements, CSR can be seen as a voluntary business contribution to the guiding societal model of sustainable development, and an active corporate engagement that goes beyond legal compliance ([9] [23]).

Werther and Chandler (2011) [24], present CSR as, "A view of the corporation and its role in society that assumes a responsibility among firms to pursue goals in addition to profit maximization and a responsibility among a firm's stakeholders to hold the firm accountable for its actions" (p.5).

Worth mentioning, since entering into the twenty-first century, more focus has been given to implementation of CSR initiatives and empirical study of CSR impacts. Schwartz and Carroll (2003) [25] reduced Carroll's four categories of corporate responsibilities (i.e. economic, legal, ethical and philanthropic) to three domain approach, namely economic, legal and ethical. The International Labor Organization (ILO) (2007) [26] redefined CSR as a way that enterprises consider the impact of their operations on society and CSR principles are integrated in enterprises' internal processes and interactions with stakeholders on a voluntary basis. Later, the European Commission (2011) [27] simplified the CSR definition as the responsibility of enterprises for their impacts on society, which indicates that enterprises should have a process in place to integrate CSR agenda into their operations and core strategies in close corporation with stakeholders. The World Business Council for Sustainable Development (WBCSD) (2012) [28] also emphasized a balance of return on financial, natural and social capitals, particularly suggesting the integration of CSR reporting into annual report.

Nowadays, companies are getting involved more and more in CSR not just in its environmental side but also in its health, social, corporate responsivity side, etc... Figure 1 shows how CSR developed from 1992 to 2010 where in 1992 80\% of companies that adopted CSR were just involved in the environmental side of CSR and the remaining $20 \%$ in health, safety and social/community. As time passed, this environmental side decreased from $80 \%$ in 1992 to less than $20 \%$ in 2010 where concepts of CSR were broadened and companies started looking at more strategies to adopt which made sustainability (environmental/social/economic), philanthropy, Integrated (Annual Financial \& Non-Financial) appear in the market.

\subsection{Why Is CSR Relevant?}

Toyne (2005) [30] contends that CSR is all about values, accountability and behavior of people in the organizations as well as the behavior of suppliers. In this sense, the organization's Human Resource function including all tasks from training, recruitment, staff retention, policies, procedures and strategy_involves 


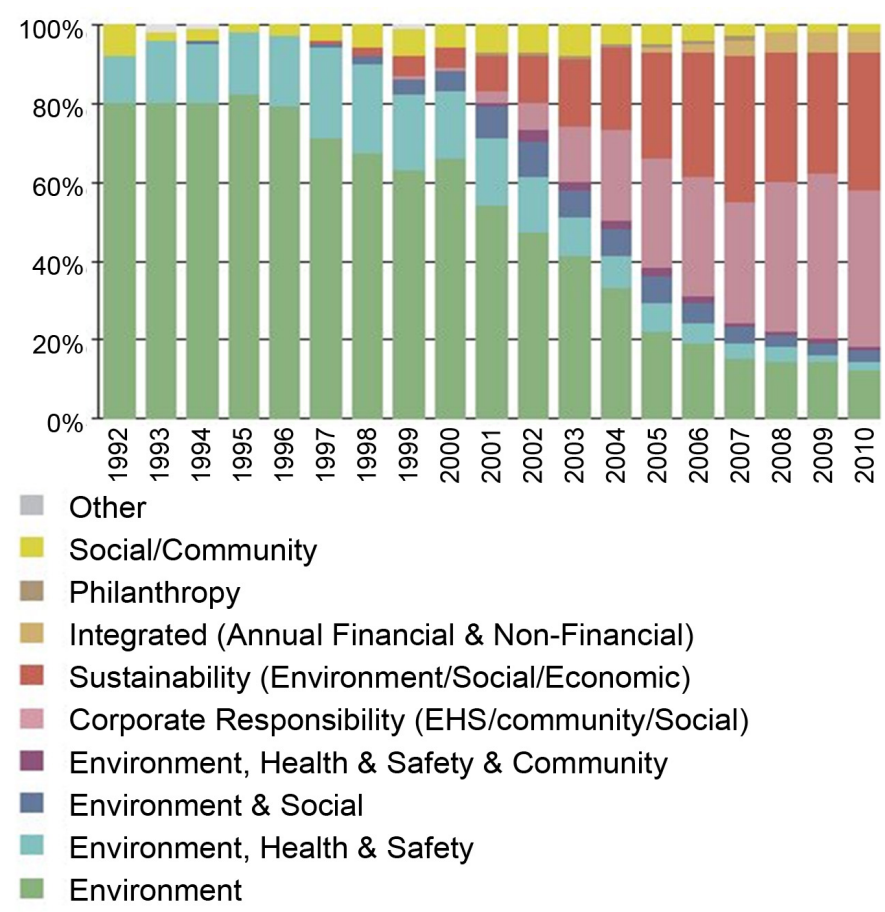

Figure 1. Global report output by type and year. Source: [29] (p. 1519).

CSR. "Traditionally HR and CSR have been led by the need for compliance and keeping up with new laws on employment as well as environmental, ethical and social issues" (Para 12). Increasingly HR managers have crucial intervention to the delivery of training to deal with the aforementioned issues in terms of organizational objectives and strategy.

On the other hand, HR abides by the organizations' stance in Corporate Governance (CG) which reflects the role of non-executive directors on how an organization is run. Corporate governance cover many areas such as financial integrity, transparency and accountability, leadership from the board and being employer of choice. CG is central to the implementation of policies and programs. Toyne (2005) [30] asserts that having good corporate governance means that the aforementioned areas are embedded in the organization and deliver to the business and to stakeholder objectives. "The HR manager has become central to this role in helping deliver culturally open and transparent organizations where dialogue is celebrated not feared" (Para 15).

CSR is a crosscutting topic under which numerous issues can be grouped including "environmental, social, economic, behavioral, technological, and cultural factors that influence health and wellness" [31] (p.10). Large multi-national companies, like for example Konica Minolta (2018) [32], were from the first to identify CSR as a potential tool to improve performance and now through their supply chain they are asking suppliers to comply with their standards.

\subsection{CSR in Lebanon}

CSR is a concept with a growing inclination in Lebanon and around the globe 
that mainly raises the notion of business accountability to a wider range of stakeholders ([4] [33]). CSR is a voluntary commitment by businesses to behave ethically and contribute to economic development while improving the quality of the environment, the life of their employees along with the local community in the society at large. Therefore, it is imperative "to align profitability with sustainability and human development" [34] (Para.3). CSR is a standardized sustainable process based on four pillars workplace, community, environment and marketplace. The aforementioned fits how the organization "Business for Social Responsibility" defines CSR "Operating a business in a matter that meets or exceeds the ethical, legal, commercial, and public expectations that society has of business"; this definition provides a broader dimension to CSR and it incorporates business decision-making that embraces and takes into account the ethical standards, legal obligations, along with a genuine respect for people, human welfare, and the environment [35] (p.3).

Despite substantial initiatives by the private, public and nonprofit sectors in Lebanon, there is still a genuine need for a sustainable group effort to address the socio economic issues Lebanon is facing. Due to lack of national awareness, corporations in Lebanon fail to tackle CSR issues correctly often resulting in non CSR practices, such as green washing, business irrelevant actions, short-term initiatives, fake awards and shallow or nonexistent reports [33].

This paper emphasizes the need to increase and sustain CSR awareness in Lebanon and such awareness must rise and be thorough in order to enhance proper CSR dialog. Good strategies must be developed and adopted by companies in order to integrate them into their policies and to do proper training on them. According to the International Institute for Sustainable Development (IISD) (2013) [36], "A key challenge facing business is the need for more reliable indicators of progress in the field of CSR, along with the dissemination of CSR strategies. Transparency and dialogue can help to make a business appear more trustworthy, and push up the standards of other organizations at the same time" (Para 13). Consequently, improving relationships and creating partnerships between corporations and the society, business associations, governmental institutions, academics, media and civil society organizations must be priority in order to make a substantial difference in the Lebanese community. Furthermore, CSR Middle East (2013) [37] claims that "though Lebanon is slowly integrating CSR into its corporate culture, the country still lags behind many of its MENA peers, particularly in regard to transparent reporting and government efforts to raise awareness" (Para 3).

Moreover, according to CSR Lebanon, which is an independent consulting firm aimed at promoting CSR, sustainable business strategies and reporting, was officially appointed by the United Nations Global Compact (UNGC) as the focal point-of-contact in Lebanon to launch the Global Compact Local Network in Lebanon by 2014. In an interview with The Daily Star, Khalid Kassar CEO and founder of CSR Lebanon, said "I hope the initiative will motivate participating 
companies to develop partnership projects to contribute to the U.N. Millennium Development Goals, among other activities" [37] (Para 9).

This research aims to assess what motivates companies in Lebanon to adopt CSR strategies. Accordingly, the research also seeks to highlight on people's awareness about CSR which in turn forces these companies to engage in CSR activities that will lead to a win-win situation.

This paper is organized as follows: In Section 2 a review of the literature related to CSR is presented. Section 3 describes the research methodology including approach, sampling, questionnaire' design and data analysis. The following Section 4 will then present the results and due discussion, and then Section 5 presents a closure to the paper with conclusions and recommendations.

\section{Literature Review}

Carroll (1999, p. 291) [10] posits that the concept of CSR has had a long and diverse history in the literature. His review (Carroll, 1979) [38] starting with Howard Bowen's (1953) book 'Social Responsibilities of the Businessman', which stands out during this period, to the $60 \mathrm{~s}$ and 70 s, where researchers attempted to focus further on CSR definition, attributes, implementation areas; as a result, more labels appeared like, "Corporate Social Responsiveness", "Corporate Social Performance", and "Social Responsibility Disclosure scale" [38] (pp. 273-283), resulted in his proposed definition: "the social responsibility of business encompasses the economic, legal, ethical, and discretionary expectations that society has of organizations at a given point in time" (p. 500). The 1980s witnessed more attempts to measure and conduct research on CSR, and alternative thematic frameworks stood out [10] (pp. 284-288). Furthermore, in the 1990s, the CSR concept transitioned significantly to alternative themes such as stakeholder theory, business ethics theory, Corporate Social Performance (CSP), and corporate citizenship (p. 292).

The 2000s mark the maturity of CSR principles whereby the focus moved to "implementation developments by linking CSR to mainstream strategies and management frameworks" [39] (p. 18). Furthermore, Carroll (2008) [40] asserts that the 2000s are characterized by empirical research on CSR and related topics such as "stakeholder theory, business ethics, sustainability, and corporate citizenship" (p. 39). In addition, since the mid-2000s, and amid the wave of research outcomes, many wondered about how the future of CSR around the world would be. Teach (2005) [41] reports two sides to the issue: The optimistic perspective depicted by Steven D. Lydenberg (2005) [42] in his book "Corporations and the Public Interest: Guiding the Invisible Hand" whereby CSR is depicted "as a major secular development, driven by a long-term reevaluation of the role of corporations in society, whereby this reevaluation is more evident in Europe, where the Stakeholder's responsibility notion is more readily assumed, but that US business people are more skeptical of this assumption" [41] (p. 31). On the other hand, Teach (2005) [41] presents the pessimistic perspective argued by David Vogel (2006) [43] in his book, "The Market for Virtue: The Potential and 
Limits of Corporate Social Responsibility", in which he critiques CSR's influence and success. According to Teach (2005) [41], Vogel is very much of the mind that CSR will not be successful until mainstream companies begin reporting some aspect of CSR as being critical to the company's past or future performance. In other words, "CSR is successful only to the extent that it adds to the bottom line and can be specifically delineated as having made such an impact. In reacting to Vogel's skepticism, it must be observed that this convergence of financial and social objectives characterizes the trajectory that CSR has taken in the past two decades" [44] (p. 113).

Since the Mid 2000s, the notion of CSR as strategy gained much support as manifested by many researchers. For example, CSR is a strategy "for growth" [7]; strategy to "leverage their competitiveness, image, reputation, and growth" [1]; and strategy to "handle unexpected incidents, long term reduction of gap between stakeholders and their expectations and company performance and finally maintaining relationship with society through interplay between actor, resources and activities" [45]. On the other hand, Hartmann (2011) [46] emphasized the strategic value of CSR in the food sector by discussing the strong impact and the high dependence on the economy, the environment and on society. CSR's threats and opportunities are increasingly shifting from the single-firm level to food supply chains and food networks bringing forward new challenges.

Brammer, Jackson, \& Matten (2012) [47] emphasized under institutional theory that CSR is not only a voluntary action but it is a part of interface between business and society. Therefore, regulation/ governance are necessary for enhancing the corporate performance of businesses through CSR whereby companies should take its social responsibilities whether historical, political or legal form.

Hejase et al., (2012a) [33] offer a review of CSR during the last five years. The aforementioned review shows that CSR is seen as integrated corporate activities [6], abiding by the legal regulations and going beyond compliance, and investing more in human capital [48], the environment and the relations with stakeholders [49]. Furthermore, "CSR is viewed as the business pursuit of sustainable development and focus on the triple bottom line by which we mean the economic, social and environmental aspects altogether" [50] (Para.2).

The last five years have shown continuous development in CSR applications, though the majority were reported via quantitative research. The Collaborating Centre for Sustainable Consumption and Production $(2102,2019)$ ([51] [52]), a German institution, conducted a major study whose report focused on consumer-oriented CSR-Communication by interviewing 40 multinational companies and 4 non-governmental organizations, this report shows the status quo and future trends in CSR-Communication. Findings include:

1) The consumer is the most important target group of CSR-Communication,

2) The trends on how communication will be conducted is more by dialogue and interaction between company and its consumers, 
3) The communication instruments used include digital and social media or point-of-sale staff.

The report outlines the challenges companies encounter when addressing the consumer and details strategies and measures (e.g. partnerships, measuring consumers' feedback) companies can use to overcome these problems. Also, Kuttner and Feldbauer-Durstmüller (2018) [53] carried out a status-quo research about CSR in family firms (FF) and found that "the academic interest in CSR in FFs has increased within the last ten years, that there are several differences and similarities between FFs and non-family firms (NFFs) in terms of CSR (major differences; e.g., CSR engagement, company, family and external characteristics), and that CSR activities have several outcomes for FFs (e.g., increased employee commitment, positive impacts on financial performance). Overall, different characteristics influencing CSR in FFs include image and reputation, ownership, family involvement, management and performance have the strongest influence on CSR in FFs" (p. 61). Furthermore, Shukla and Challare (2019) [54] carried out another status-quo research in the Indian continent and found that, "over the last few years, the concept of CSR has a clear transition from giving as an obligation or charity to giving as a strategy. Review of the case studies and work done on CSR by companies in India suggests that the CSR is slowly moving away from charity and dependence and starting to build on empowerment and partnership" (p. 31).

The previous paragraphs provided a brief summary of CSR evolution. Western countries have recorded their CSR experiences, and how their multinational corporations have capitalized on CSR to face the challenges and to assure their businesses' sustainability. One success story to validate the aforementioned is Gildan, one of the world's largest manufacturers of activewear, underwear and socks, whose president and CEO Glenn J. Chamandy, contends that they "understand clearly that our success and future growth demands that we pursue continuous improvements by constantly integrating sustainable solutions and investing in innovative technologies" [55] (p. 5). Gildan is recognized for its commitment to CSR and for the company's collective efforts and ongoing commitments to operate sustainably and responsibly. In 2017, Gildan was included in the Dow Jones Sustainability World Index (DJSI World Index) for the fifth consecutive year, once again as the only North American company in the Textiles, Apparel and Luxury Goods industry group listed in the DJSI World Index [55]. Furthermore, for the 10th consecutive year, Gildan in its active role as a catalyst for change in the international markets, Gildan also received the FUNDAHRSE CSR seal that recognizes organizations in Honduras that demonstrate leading practices related to employee and community relations, human rights, labour, governance, environmental and operational practices [55] (p. 6).

\subsection{CSR in the Arab World}

Arshad, Muhammad and Al Astal (2015) [56] cite several researchers who inves- 
tigated CSR, such as: Jahamani (2003) [57] who reported that United Arab Emirates' managers are aware of green accounting which concentrates on CSR issues of environment; Kamla (2007) [58] who assessed several CSR dimensions including environmental, economic, and social. Her study was carried among nine of the Arab Middle East countries, which are Kuwait, Qatar, United Arab Emirates, Saudi Arabia, Oman, Bahrain, Jordan, Egypt and Syria; Katsioloudes and Brodtkorb (2007) [59] who surveyed 403 companies as to their awareness of the issue of corporate social responsibility, covering three dimensions, namely, environmental, consumer protection and community affairs; Rettab, Brik and Mellahi (2009) [60] who surveyed 280 organizations in Dubai, found that there is a positive relationship between the disclosure of CSR and the firm's performance; Jamali, Sidani and El Asmar (2009) [61] who surveyed 333 managers working in Lebanon, Syria and Jordan, assessing managerial perspectives towards CSR and found that there are certain commonalities and minor divergences in CSR orientations; and Hossain and Hammami (2009) [62] who conducted their study on Qatar's disclosure of corporate social responsibility.

Moreover, Hejase et al. (2012a) [33] report that "CSR is a new and relatively unknown phenomenon among SMEs in Lebanon as $42 \%$ of the respondent managers and employees (sample of 100 persons) indicated that they have only a little knowledge of the subject, and that they haven't done much to enrich their knowledge of or to participate in CSR programs or activities, though they seemed to have some idea of what CSR could mean for their companies" (p. 17). Abu Farha and Alkhalaileh (2016) [63] suggest that still Jordan need an empirical assessment of corporate social responsibility based on a strong infrastructure combined of both current practices and stakeholders' perception of CSR concept. Hejase et al. (2017) [3] who surveyed 200 employees and managers, found that the top four preferred CSR activities which impact the Lebanese consumer are related to charity (philanthropic). From one side, the aforementioned observation fits Jamali et al.'s (2009) [61] modern paradigm of CSR. In addition, Hejase et al. (2017) [3] found that surprisingly, in Lebanon, one notes the emphasis on economic and environmental initiatives and projects carried out by Lebanese corporations which insinuate classical CSR orientation. Finally, Makaron (2019) [4] examined the impact of CSR activities oriented to stakeholders including employee, customer, and society. Research was conducted in the Lebanese banking sector with 214 employees. Macaron provided "evidences to assess the visibility of CSR activities in the eyes of stakeholders and to identify which domains are to be enhanced in order to set more effective social strategies in organizations to reach the identification and satisfaction of employee" (p. 35).

\subsection{CSR Process}

The implementation of CSR is a complex process. In order for it to be successful it must be integrated into every part within the company. However, it must be very clear that corporations follow their own specific and tailored implementa- 
tion frameworks to plan, design, implement and monitor and measure their CSR projects, keeping in mind that there is no "one fits all" because each corporation is unique and has its specific strategic intent.

McWilliams, Siegel, \& Wright (2006) [64] recommend that CSR must be incorporated into the core of a manager's strategy and thoughts in order to facilitate its translation, a fact that will allow such trend to be embraced by every employee in the organization, resulting in corporations operating responsibly in every function. The aforementioned is fits Hohnen's (2007) [6] recommendation that corporations may follow a roadmap containing guidelines and each will then adjust according to objectives, needs, and resources, whereby "the road map consists of four main steps: planning, doing, checking, and improving" (p. 19). Years later, Chandler and Werther, Jr. (2013) [65] present a new framework for strategic CSR implementation which according to the authors is divided into four components namely, "first, that firms incorporate a CSR perspective within their strategic planning process; second, actions taken are directly related to core operations; third, firms must incorporate a stakeholder perspective; and fourth, shift from a short-term perspective to managing the firm's resources and relations with key stakeholders over the medium to long term" (p. 65).

\subsection{Entrepreneurial Opportunities}

Paul Light (2008) [66] proposes that the Social Entrepreneurship can be defined as the interaction of four components namely, the entrepreneur, the idea, the opportunity and the organization, which could help entrepreneurs to develop and better implement their initiatives, under the proviso that social problems are not absolute and therefore these components must be considered depending on the context. Building on the aforementioned, Silva Niño (2015) [67] proposes that as "Social Entrepreneurship is intended to meet common needs resulting of the economic system and Corporate Social Responsibility, is the result of company ethical reflection based on interdependence and reciprocity of it to society, both paths are closely related to the creation of sustainable social value, but do not get in the same way, so it requires both" (p. 85). Furthermore, Kaufman (2016) [68] recommends that "Cost-efficiency is one of the first responsibilities of any entrepreneur, and engaging in responsible, sustainable practices can be a great way to cut costs" (Para 7). Moreover, Kaufman posits that "More and more, consumers simply expect businesses and corporations to help make the world a better, nicer place. That might seem, to many would-be entrepreneurs, like a strange burden to place on a money-making enterprise, but it's essential to see CSR as an opportunity" (Para 13). Finally, Szegedi, Fülöp and Bereczk (2016) [69] assert that "Analysis of the concepts of CSR and social innovation have shed light on the way in which CSR is integrated into corporate strategy can itself be considered a social innovation. Corporate social innovation and social entrepreneurship both attempt to contribute to solving some social problem, while maintaining economic sustainability" (p. 1547). 


\subsection{Benefits of CSR}

According to Hohnen (2007, pp. 10-12) [6] and Asemah, Okpanachi and Edegoh (2013, pp. 50-54) [70], there are several potential benefits for firms implementing CSR, these include: Better anticipation and management of an ever expanding spectrum of risk; improved reputation management; enhanced ability to recruit, develop and retain staff; Improved innovation, competitiveness and market positioning; Enhanced operational efficiencies and cost savings; Improved ability to attract and build effective and efficient supply chain relationships; Enhanced ability to address change; More robust "Social Licence" to operate in the community; Access to capital; Improved relations with regulators; and A catalyst for responsible consumption.

\subsection{Loss of Focus}

According to Hejase et al. (2017, p. 8) [3], there are several constraints to CSR strategy and anyone of them may delay or even stop the project totally. Lack of clear vision is a basic constraint that may hinder the success of any CSR strategy because if corporate vision is not clear and strategically poor, the corporate will not get to healthy goals; this is seen when regular level staff with no strategic experience manage such programs and take charge of them. Another important loss of focus happens when companies that abide by CSR guidelines may do so more from fear of public backlash than because they believe it is good for long-term business performance. While most parties generally agree that taking care of customers is good in the long run, expensive requirements in human rights, environmental sustainability and community development may be too much to ask of many companies.

Despite CSR being a very significant issue, Lebanese companies, organizations and service industries are not quite embracing it as a part of their business plan. Failing to realize the importance of CSR in the community and the low awareness levels about the topic will eventually have negative results on the companies themselves. Moreover, CSR is still a new term in Lebanese society as its benefits are vague and unclear. People's perception about CSR in Lebanon is still unclear and whether companies are adopting CSR strategy are based on how people perceive CSR to be.

\subsection{Research Objectives}

This study aims to assess the status quo of CSR in Lebanon, whether it is how people are aware of this concept or how much are Lebanese companies adopting CSR.

\section{Research Methodology}

This research is exploratory and explanatory in the sense that it explores a target sample of Lebanese employees' and managers' awareness regarding CSR and the extent of CSR adoption by Lebanese organizations. 
Quantitative analysis is based on a structured questionnaire, and all responses were entered into the SPSS version 23 program "Statistical Product and Service Solutions, an IBM product since 2009" [71] (p. 58). The study is performed using exploratory statistics; data tables including frequency and percentage distributions are used. Moreover, cross tabs and regression analysis are performed to study relationships between variables that may add value to the findings of the research.

\subsection{Sample Selection}

The sample of respondents is chosen based on judgment and convenience as to the subjects' willingness to participate. They are employees and managers from the services sector (hotelier, banking, telecommunications and constructional sector) in order to cover different areas rather than stressing on specific industry. The population targeted consisted of 390 employees and managers working in the aforementioned business entities selected from prime locations in the city of Beirut, however the aforementioned personnel lives in different places in Lebanon. The sample size is estimated using Yamane's (1967) [72] formula [ $\mathrm{n}=$ $\left[\mathrm{N} /\left(1+\mathrm{Ne}^{2}\right)\right]$ with $\mathrm{N}$ being the population, $\mathrm{n}$ the sample and $\mathrm{e}=5 \%$ resulting in 197.5 or around 198 persons. A total of 200 questionnaires were distributed during the months of April and June, 2019. However, 102 questionnaires were valid for the research after removing incomplete, half-empty and wrongly filled questionnaires. The total number of filled survey questionnaires received was 133; 99 respondents filled the questionnaire in person on a hard copy and were collected afterward, and 34 filled the questionnaire on soft copy and were collected via email. 32 questionnaires were disqualified, 24 of which were not filled adequately, 6 were half empty, and 2 were not returned. Therefore, the response rate is $51 \%(102 / 200)$. This low response is partly due to the strictness of the companies in allowing employees and managers respond to questionnaires especially that the human resource departments had to issue permissions.

\subsection{Questionnaire Design}

The questionnaire begins with an opening statement to the topic and its motivation, followed by another statement of confidentiality, in which the researchers pledge that the collected information is solely used for academic research and that the anonymity of the respondents is guaranteed. The questionnaire consists of 29 questions divided into four sections. The research tool used in the current project is a systematic and structured questionnaire that is divided into four parts:

1) Section one is designed to assess the respondents' awareness about CSR. Questions one through seven studies how much the respondents are aware of the concept of CSR which checks the technical knowledge about the subject that is being studied.

2) Section two is designed to assess the respondents' attitude and behavior 
towards CSR. In this section seven questions explore the respondents' attitudes and behaviors towards the concept of CSR.

3) Section three is designed to assess the respondents' implementation of CSR. In this section also 7 questions explore how the respondents are inclined to implement CSR in their work environment.

4) Section four is designed to access the respondents' demographics. In this section seven questions are used describing the age, gender, location, type of work, marital status, etc...

Finally, the questionnaire ends with one open-ended question that gives the respondents the opportunity to express themselves freely regarding the research subject.

\subsection{Data Analysis}

All responses are entered into the SPSS version 23 program. The study is performed using exploratory and descriptive statistics; data tables including frequency and percentage distributions are used. Moreover, cross tabs and regression analysis to study relationships between variables that may add value to the findings of the research are performed.

\section{Results and Findings}

\subsection{Demographics}

Respondents are $42.2 \%$ females and $57.8 \%$ males, $54.9 \%$ of them are single, $40.2 \%$ are married and $4.9 \%$ are divorced or widowed. As for respondents' age, their mean average age is 31 years; they are split into five groups: $24.5 \%$ for under 25 years old, $39.2 \%$ for 26 to 32 range, $19.6 \%$ for 33 to 38 range, $6.9 \%$ for 39 to 44 range, and $9.8 \%$ for older than 44 years. Also, $59 \%$ of the respondents hold an MBA degree, $26.5 \%$ hold a bachelor degree, $8.5 \%$ hold a doctorate, and $2.5 \%$ are high school graduates.

In addition, results show that respondents work in the following fields: $24.5 \%$ in Finance, Insurance and Banking; 29.4\% in Construction; 34.3\% in Hotel and Food Services; and, the remaining $11.8 \%$ work in Telecommunications. Furthermore, $14.7 \%$ of the respondents reside in North Lebanon; $11.8 \%$ reside in the South; $45.1 \%$ reside in Beirut; and, 28.4\% reside in Mount Lebanon. Moreover, $95.1 \%$ of the respondents are working while $4.9 \%$ are not but looking for a job.

\subsection{Knowledge of the Respondent}

\section{1) Familiarity with CSR Programs}

Results show that $70.6 \%$ of the respondents are acquainted with what CSR is, while $29.4 \%$ didn't know what it means.

2) Searching for the organizations' CSR practices while applying for a job

$54 \%$ of the respondents responded by "definitely yes and yes" when asked if their job search includes asking for the organizations' CSR practices, $17.6 \%$ were neutral about the question, while $28.4 \%$ negated the question by responding 
"definitely no and no". Responses are depicted in Figure 2. This shows that more than half of the respondents do search for organizations that practice CSR.

3) Organizations practicing CSR impact their image

$78.4 \%$ of the respondents believe that organizations which practice CSR affect their image, while $21.6 \%$ did not agree.

4) Companies' CSR initiatives motivate job seekers' interest to apply

$69.6 \%$ of the respondents agreed that a company's CSR initiatives motivates them to apply for a job at this company, 30.4\% did not agree.

5) Role of the employee to reduce one's enterprises' environmental impact

Results show that $48 \%$ of the respondents agreed that they tried to reduce their enterprise's environmental impact by participating in company campaigns and activities, 20.6\% responded that their efforts were partial, 15.7\% disagreed, $12.7 \%$ responded that they do not know, and $2.9 \%$ preferred not to say or express their opinion.

\section{6) Source of knowledge about CSR}

Table 1 shows that "Social Media" is the source with highest choice (56.9\%) followed by "Websites" (42.2\%) including companies, Non-governmental organizations, news channels, etc... the sources less used are news bulletins, newspapers and reports.

\section{7) Acquaintance with Lebanese institutions having CSR programs}

Table 2 shows that respondents named more banks than other institutions, followed by hotels and one company each from the telecommunications and constructions industries. This is most possibly because of where the respondents work and interact mostly.

\subsection{Attitude and Behavior of the Respondents}

Several statements have been assessed using 5-level Likert scale approach whereby

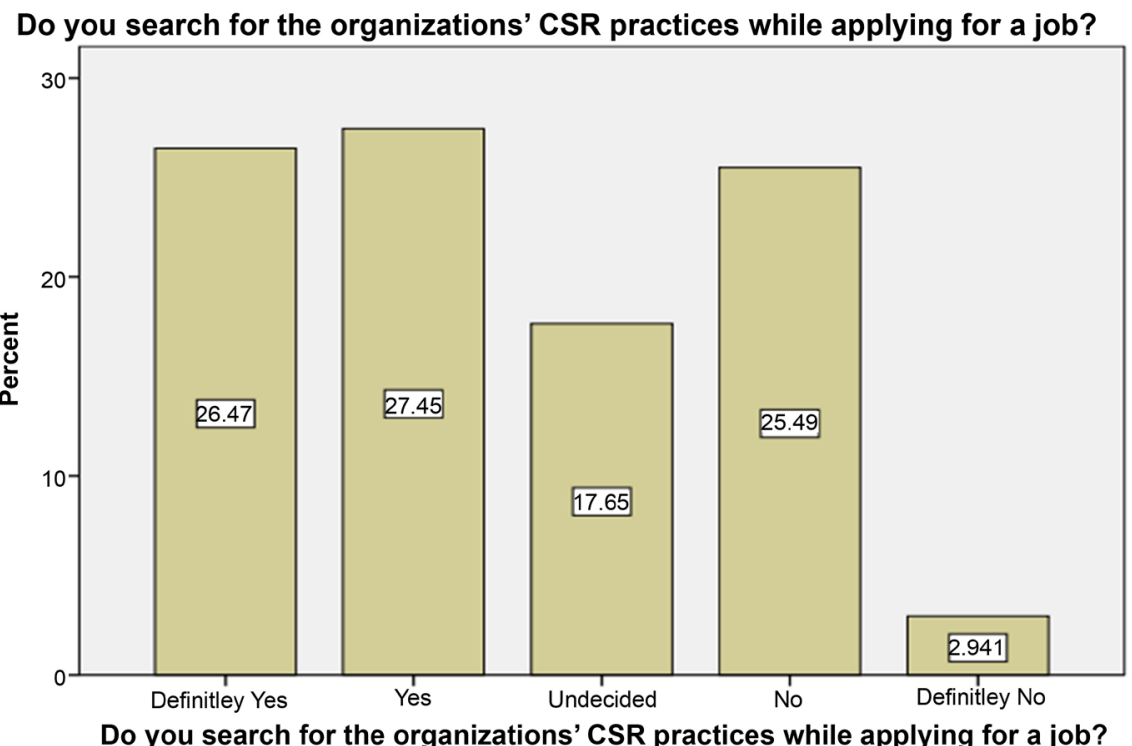

Figure 2. Searching for the organizations' CSR practices while applying for a job. 
Table 1. Source of knowledge about CSR programs.

\begin{tabular}{ccc}
\hline Source of knowledge about CSR & Yes, \% & No, \% \\
\hline News Bulletins & 20.8 & 79.2 \\
Reports & 19.6 & 80.4 \\
Newspapers & 21.6 & 78.4 \\
Social Media & 56.9 & 43.1 \\
Websites & 42.2 & 57.8 \\
Weekly News Video Magazines & 10.9 & 89.1 \\
Others [Casual talk] & 2.9 & 97.1 \\
\hline
\end{tabular}

Table 2. Companies identified of having a CSR program.

\begin{tabular}{ccc}
\hline If you know of any Lebanese company that has a CSR Program & Yes, \% & No, \% \\
\hline BankMed & 30.3 & 69.7 \\
Bank Audi & 21.2 & 78.8 \\
BLOM Bank & 18.2 & 81.8 \\
Byblos Bank & 15.2 & 84.8 \\
Inter Continental Phoenicia Hotel & 36.4 & 63.6 \\
Inter Continental Le Vendome Hotel & 36.4 & 63.6 \\
Alfa telecommunications & 21.2 & 78.8 \\
TAJCO Construction Group & 30.3 & 69.7 \\
\hline
\end{tabular}

the following codes are used-SA: Strongly Agree; A: Agree; N: Neutral; D: Disagree; and, SD: Strongly Disagree. However, results are consolidated by adding SA and A as well as D and SD for simplicity and to clearly show the total extent of agreement or disagreement: hence, A stands for Agreement and D for Disagreement. Results shown in Table 1 are depicted in percent.

Table 3 shows that $72.6 \%$ of the respondents' companies have a CSR strategy (45.10\% strongly agree and $27.5 \%$ agree); $71.7 \%$ of organizations encourage employees to participate in local community activities (35.3\% strongly agree and $36.4 \%$ agree); $73.4 \%$ of the respondents' organizations give regular financial support to local community activities and projects (30.7\% strongly agree and $42.7 \%$ agree); $74.5 \%$ of the respondents' organizations communicate their values to customers, business partners, suppliers and other stakeholders; $79.2 \%$ of the organizations adopt a Corporate Social Responsibility strategy; and finally with lowest agreement level, $68.6 \%$ of the organizations assess the impact of their business on the stakeholders.

Several statements have been assessed using 5-level Likert scale approach whereby the following codes are used-VI: Very Important; I: Important; N: Neutral; NI: Not Important; and, NIA: Not Important at All. However, results are consolidated by adding VI and I as well as NI and NIA for simplicity and to clearly show the total extent of importance or non-importance: hence, I stands 
Table 3. Attitude towards CSR.

\begin{tabular}{|c|c|c|c|}
\hline Statement & A & $\mathrm{N}$ & $\mathrm{D}$ \\
\hline My organization has a CSR initiatives/strategy & 72.6 & 18.5 & 8.9 \\
\hline $\begin{array}{l}\text { My organization encourages employees to participate in local community } \\
\text { activities (e.g. providing employee time and expertise, or other practical } \\
\text { help). }\end{array}$ & 71.7 & 22.5 & 5.8 \\
\hline $\begin{array}{l}\text { My organization gives regular financial support to local community } \\
\text { activities and projects (Ex: charitable donations or sponsorship) }\end{array}$ & 73.4 & 19.8 & 6.8 \\
\hline $\begin{array}{l}\text { My organization communicates its values to customers, business partners, } \\
\text { suppliers and other stakeholders (e.g. in sales presentations, marketing } \\
\text { material or informal communication) }\end{array}$ & 74.5 & 21.6 & 3.9 \\
\hline My organization assesses the impact of its business on the stakeholders & 68.6 & 24.5 & 6.9 \\
\hline My organization adopts a Corporate Social Responsibility strategy & 79.2 & 13.8 & 7.0 \\
\hline
\end{tabular}

for Important and NI for Not Important. Results shown in Table 4 are depicted in percent.

Table 4 shows that the majority of the respondents agreed about most of the motivators which motivate their organizations to adopt a CSR strategy including top management ethical motivation, improved corporate image, commercial advantages, increased efficiency, employees' satisfaction, external pressures, and public incentives. The overall average of importance of the aforementioned factors is $74 \%$ which is acceptable.

\subsection{Implementation of CSR}

This section explores the readiness of the respondents' Lebanese institutions to embark in a broad selection of CSR activities. Table 5 shows that the respondent's opinion about whether the implementation of CSR should be the responsibility of every company whereby $76.47 \%$ agreed. Similar agreement percentages were scored for the questions related to "governments should reward companies that adopt CSR" with 79.4\%; and "companies should allocate a CSR budget" with $76.5 \%$.

Table 6 is rather an important collection of facts. The three highest agreed upon company actions to reduce environmental impact are waste recycling, energy saving, and use of renewable resources even though the percentages are not too high, other actions captured very low agreement levels around $25 \%$. Environmental activities are considered classical moves by Lebanese organizations, however results here show that the involved institutions consider such actions more for manufacturing companies. Therefore, service companies invest more on campaigns of high visibility like the first three choices which are considered a daily issue for the Lebanese population (Dr. Bassam Hamdar, personal communication, Lebanese Economist).

Results also show that when respondents were asked about how the government should reward companies that adopt CSR strategies, 67.6\% support the 
Table 4. Reasons that may affect a company to adopt CSR practices.

\begin{tabular}{cccc}
\hline $\begin{array}{c}\text { Statement: Reasons that may affect a company to } \\
\text { adopt CSR practices are }\end{array}$ & I & N & NI \\
\hline Ethical motivation of top management & 84.3 & 14.7 & 1.0 \\
Promote corporate image & 82.0 & 17.0 & 1.0 \\
Commercial advantages to new markets & 78.5 & 19.5 & 2.0 \\
Increase of efficiency & 71.6 & 21.6 & 6.8 \\
Greater employee satisfaction & 65.7 & 28.4 & 5.9 \\
Pressure from consumer association and media & 74.5 & 21.6 & 3.9 \\
Public Incentives & 61.8 & 35.3 & 2.9 \\
\hline
\end{tabular}

Table 5. Implementation issues.

\begin{tabular}{lcc}
\hline \multicolumn{1}{c}{ Question } & Yes & No \\
\hline $\begin{array}{l}\text { Do you agree that implementing CSR should be the responsibility of every } \\
\text { company? }\end{array}$ & 76.5 & 23.5 \\
$\begin{array}{l}\text { Do you think governments should reward companies that adopt CSR? } \\
\begin{array}{l}\text { Do you agree with CSR budgets allocated by your company? } \\
\text { P. }\end{array}\end{array}$ & 79.4 & 20.6 \\
\hline
\end{tabular}

Table 6. Respondents' opinions about their companies' adopted actions to reduce environmental impacts.

\begin{tabular}{ccc}
\hline Did your company adopt “ $\_$” to reduce environmental impact? & Yes, \% & No, \% \\
\cline { 2 - 4 } Energy Saving & 59.8 & 40.2 \\
Waste Recycling & 62.7 & 37.3 \\
Mobility Management (Car Pooling, Car Sharing, ...) & 25.5 & 74.5 \\
Sustainable Packaging & 22.5 & 77.5 \\
Development of Environmental Friendly Products & 35.3 & 64.7 \\
Life Cycle Assessment Processes & 21.6 & 78.4 \\
Environmental Management System & 26.5 & 73.5 \\
Use of Renewable Resources & 40.2 & 59.8 \\
\hline
\end{tabular}

"decrease of taxes by certain percentages", followed by the option that "governments must promote companies on TVs" $22.6 \%$, providing awards with $3.9 \%$, and the remaining simply opined that government should not intervene.

The respondents being from the service sector and their majority from the banking and hotel industry, it is obvious that they chose going green and employee safety as issues to be dealt with currently. Child labor and women rights come next with less than $25 \%$ agreement (Table 7).

Table 8 shows that the selected CSR community actions are traditional in nature with $48 \%$ opting for donations to organizations having social or environmental utility, $40.2 \%$ opting for sponsoring sports and cultural events, and $31.4 \%$ 
Table 7. Most recent problems faced by companies.

\begin{tabular}{ccc}
\hline Did your company face “_ " problem recently & Yes, \% & No, \% \\
\hline Employee Safety & 37.3 & 62.7 \\
Going Green & 43.1 & 56.9 \\
Children Labor & 22.5 & 77.5 \\
Women's Rights & 18.6 & 81.4 \\
Not Applicable & 27.5 & 72.5 \\
\hline
\end{tabular}

Table 8. CSR community related actions.

\begin{tabular}{ccc}
\hline $\begin{array}{c}\text { Which are concrete actions towards community } \\
\text { in which your company operates: }\end{array}$ & Yes, \% & No, \% \\
\hline $\begin{array}{c}\text { Donation to organizations having social or environmental utility } \\
\text { Sponsorship of sport and cultural events }\end{array}$ & 48.0 & 52.0 \\
Cause Related Marketing campaign & 40.2 & 59.8 \\
Partnership projects of social solidarity & 23.5 & 76.5 \\
Corporate foundation & 31.4 & 67.6 \\
Corporate voluntary & 26.5 & 73.5 \\
None & 30.4 & 69.6 \\
\hline
\end{tabular}

opting for partnership projects of social solidarity including illiteracy, health, women issues, etc..., among others. It is concluded that charity, environmental, and cultural activities in general carry the highest interest in their minds, a result that fits with findings and observations by other researchers ([3] [33] [61]).

\subsection{Cross Tabulation}

\section{Crosstabulation of "Age" versus "Familiarity with CSR Programs"}

Cross-tabulation testing of the variable "Are you familiar with CSR Programs?" versus the variable "Age" confirms statistically that respondents' age influences their familiarity with CSR programs (Pearson's $\mathrm{R}=-0.205$, P. sig. $=$ $0.039<\alpha=5 \%)$. However, the relationship is weak and negative though statistically significant. The negative direction reflects a negative trend that is, the younger are more familiar with CSR as compared with the more mature respondents.

Crosstabulation of "Gender" versus "Familiarity with CSR Programs"

Cross-tabulation testing of the variable "Are you familiar with CSR Programs?" versus the variable "Gender" did not confirm statistically that respondents' gender influences their familiarity with CSR programs (Pearson's $\mathrm{R}=$ -0.115 , P. sig. $=0.248>\alpha=5 \%$ ). However, the relationship is very weak and negative (due to coding direction) and not statistically significant. The negative direction reflects a negative trend that is, the younger are more familiar with CSR as compared with the more mature respondents. Furthermore, it is worth 
mentioning that males are slightly more familiar (38.2\%) with CSR programs than females (32.4\%).

Crosstabulation of "My organization has a CSR initiatives/strategy" versus "My organization encourages employees to participate in local community activities (e.g. providing employee time and expertise, or other practical help)"

Cross-tabulation testing of the variable "My organization has a CSR initiatives/strategy?" versus the variable "My organization encourages employees to participate in local community activities (e.g. providing employee time and expertise, or other practical help)" confirms statistically that respondents' organizational CSR strategy influences their involvement in local community activities (Pearson's $\mathrm{R}=0.770$, P. sig. $=0.000<\alpha=5 \%$ ). However, the relationship is strong and positive and statistically significant. The outcome is natural since an organization with clear CSR initiatives/strategy mindfully encourages employees to get involved, and such involvement is overseen by the corresponding HR function.

Crosstabulation of "My organization has a CSR initiatives/strategy" versus "My organization adopts a Corporate Social Responsibility strategy"

Cross-tabulation testing of the variable "My organization has a CSR initiatives/strategy?" versus the variable "My organization adopts a Corporate Social Responsibility strategy" confirms statistically that respondents' organizational CSR initiatives/strategy influences the decision of an organization to officially institute a CSR strategy (Pearson's $\mathrm{R}=0.681$, P. sig. $=0.000<\alpha=5 \%$ ). However, the relationship is strong and positive and statistically significant. The CSR initiative reflects the top management commitment which in turn leads to the formal institution of a CSR strategy which is usually shared with all concerned stakeholders.

\subsection{Causal Analysis}

According to Hejase \& Hejase (2013) [71], a "Multiple Regression Model is needed when the researcher faces the scenario where more than one independent variable causes variations in the dependent variable under study" (p. 478). Therefore, the next step is to explore and group possible relationships which may help analyze the impact of identified factors by the respondent employees [explanatory variables] on organizational CSR strategy. For such purpose and to account for the qualitative meaning of the multivariable relationships, standardized betas are used. Next, the possible final model is depicted,

$$
Y=\beta_{1} X_{1}+\beta_{2} X_{2}+\beta_{3} X_{3}+\beta_{4} X_{4}+\beta_{5} X_{5}+\beta_{6} X_{6}+\beta_{7} X_{7}+\beta_{8} X_{8}+\beta_{9} X_{9}
$$

\section{Regression model}

Table 9 shows that causal analysis has led to the generation of one multivariable relationship. The resultant model is generated using Stepwise analysis, whereby independent variables are assessed through several calculation cycles in which all independent variables are assessed based on $95 \%$ statistical certainty. 
Table 9. Regression model with standardized betas and VIF values.

\begin{tabular}{|c|c|c|c|c|c|}
\hline No. & $N=33$ & Code & Stand $\beta$ & Sig P & $\begin{array}{l}\text { Collinearity } \\
\text { Stats VIF }\end{array}$ \\
\hline 1 & $\begin{array}{l}\text { My organization encourages employees to } \\
\text { participate in local community activities (e.g. } \\
\text { providing employee time and expertise, or } \\
\text { other practical help). }\end{array}$ & S2_Q2 & $0.7220^{* * *}$ & 0.000 & 1.370 \\
\hline 2 & $\begin{array}{l}\text { Which are concrete actions towards } \\
\text { community in which your company } \\
\text { operates?: Sponsorship of sport and cultural } \\
\text { events }\end{array}$ & S3_Q7B & $-0.2475^{\star * *}$ & 0.000 & 1.594 \\
\hline 3 & $\begin{array}{l}\text { Please state if you have seen CSR on "Social } \\
\text { Media" }\end{array}$ & S1_Q5D & $0.1946^{* * *}$ & 0.002 & 1.466 \\
\hline 4 & $\begin{array}{l}\text { Please state if you have seen CSR in } \\
\text { "Newspapers" }\end{array}$ & S1_Q5C & $0.2766^{* * *}$ & 0.000 & 1.401 \\
\hline 5 & $\begin{array}{l}\text { Please state if you have seen CSR in } \\
\text { "Reports" }\end{array}$ & S1_Q5B & $-0.2271^{* * *}$ & 0.000 & 1.180 \\
\hline 6 & $\begin{array}{l}\text { If you know any Lebanese company that has } \\
\text { a CSR Programs, please mention them: Alfa } \\
\text { Telecom }\end{array}$ & S1_Q7G & $-0.3959^{* * *}$ & 0.000 & 1.764 \\
\hline 7 & $\begin{array}{l}\text { If you know any Lebanese company that has } \\
\text { a CSR Programs, please mention them: Bank } \\
\text { Audi }\end{array}$ & S1_Q7B & $0.2442^{* * *}$ & 0.001 & 1.820 \\
\hline 8 & $\begin{array}{l}\text { My organization communicates its values to } \\
\text { customers, business partners, suppliers and } \\
\text { other stakeholders (e.g. in sales } \\
\text { presentations, marketing material or } \\
\text { informal communication). }\end{array}$ & S2_Q4 & $0.1548^{* * *}$ & 0.008 & 1.310 \\
\hline 9 & $\begin{array}{l}\text { Do you think that organizations which } \\
\text { practice CSR affect its image? }\end{array}$ & S1_Q3 & $0.1984^{\star * *}$ & 0.001 & 1.282 \\
\hline
\end{tabular}

Dependent variable: My organization adopts a Corporate Social Responsibility strategy. ${ }^{*}$ Signifcance $95 \%$; $* * *$ Significance $99 \%$.

All variables, whose calculated probabilities are greater than the standardized error of 5\%, are excluded. Results for Model 1 that describe how respondents view their standpoint on CSR related factors by providing their own self-assessment are grouped into nine explanatory variables.

\section{Resultant Model}

My organization adopts a Corporate Social Responsibility strategy $=0.722$ [My organization encourages employees to participate in local community activities (e.g. providing employee time and expertise, or other practical help)] 0.2475 [Which are concrete actions towards community in which your company operates?: Sponsorship of sport and cultural events] +0.1946 [Please state if you have seen CSR on "Social Media"] + 0.2766 [Please state if you have seen CSR in "Newspapers"] - 0.2271 [Please state if you have seen CSR in "Reports"] + 0.1984 [Do you think that organizations which practice CSR affect its image?] 0.3959 [If you know any Lebanese company that has a CSR Programs, please 
mention them: Alfa Telecom] + 0.2442 [If you know any Lebanese company that has a CSR Programs, please mention them: Bank Audi] + 0.1548 [My organization communicates its values to customers, business partners, suppliers and other stakeholders (e.g. in sales presentations, marketing material or informal communication)].

Model "9" (Table 9) is obtained after 9 cycles of stepwise calculations. Results indicate that Model " 9 " is quantitatively suitable due to the strong values of the coefficient of correlation $(\mathrm{R}=0.975)$ and the coefficient of determination (Adj. $\mathrm{R}^{2}=0.931$ ), respectively (see Table 10 ); however, the model is also qualitatively acceptable and statistically significant with an associated probability of 0.000 (which is less than $\alpha=0.05$ ). ANOVA testing (Table 11) indicates that the regression equation predicts better than would be expected by chance. The F-value $=49.31$ with an associated probability of Sig P. $=0.000<\alpha=5 \%$. Furthermore, Model 9 has all standardized Betas which are statistically significant with probabilities $(0.000,0.000,0.002,0.000,0.000,0.000,0.001,0.008$, and 0.001 all less than the standard error of $1 \%)$. Furthermore, the Variance Inflation Factor (VIF) is $1 /$ Tolerance, it is always greater than or equal to 1 . Values of VIF from Table 9 shows that these do not exceed 2 indicating no multicollinearity presence. Therefore, there is no correlation or bidirectional relationship among the predictor variables, and all the predictor or explanatory variables are suitable to form a causal relationship using regression.

This model shows that $93.1 \%$ of the variation in the dependent variable is explained by the explanatory variables. The explanatory variables support the notion that planned engagement of employees in local community activities fits strongly an organization having CSR strategy and effective role in social work [24], dissemination of organizational values to stakeholders provides transparency and strategic intention ([3] [7] [30]), acquaintance with Lebanese organizations which reports CSR initiatives or not [case of Bank Audi, one of the first banks in Lebanon which formally issues annual CSR report while Alfa Telecom reports in its Website] [33] (p. 10), CSR activities improve organizational image

Table 10. Model summaryj.

\begin{tabular}{|c|c|c|c|c|c|c|c|c|c|c|}
\hline \multirow{2}{*}{ Model } & \multirow{2}{*}{$\mathbf{R}$} & \multirow{2}{*}{ R Square } & \multicolumn{2}{|c|}{ Adjusted R Std. Error of the } & \multicolumn{5}{|c|}{ Change Statistics } & \multirow{2}{*}{ Durbin-Watson } \\
\hline & & & Square & Estimate & R Square Change & F Change & df1 & $\mathrm{df} 2$ & Sig. F Change & \\
\hline 9 & $0.975^{\mathrm{i}}$ & 0.951 & 0.931 & 0.217 & 0.018 & 8.542 & 1 & 23 & 0.008 & 1.697 \\
\hline
\end{tabular}

Note: After 9 cycles of calculations.

Table 11. ANOVA ${ }^{\mathrm{a}}$.

\begin{tabular}{ccccccc}
\hline \multicolumn{2}{c}{ Model } & Sum of Squares & df & Mean Square & F & Sig. \\
\hline & Regression & 20.974 & 9 & 2.330 & 49.310 & $0.000^{j}$ \\
9 & Residual & 1.087 & 23 & 0.047 & & \\
& Total & 22.061 & 32 & & & \\
\hline
\end{tabular}

${ }^{a}$ Dependent Variable: My organization adopts a Corporate Social Responsibility strategy. 
[1], Employee awareness is positively influenced by social media and newspapers as compared to organizational reports, a fact that helps organizational CSR awareness focus towards employees as well as other stakeholders ([3] [4] [73]).

\subsection{Robustness Analysis}

The stability or the robustness of the model were tested using "Residual tests" which included Cook and Mahalanobis distance analyses, Breusch-Pagan and Koenker tests, and Heteroskedasticity Test.

Table 12 shows that the Cook and Mahalanobis distance analyses indicate that there are no Multivariate outliers present. Furthermore, Figure 3 shows that

Table 12. Residuals statistics ${ }^{\mathrm{a}}$.

\begin{tabular}{cccccc}
\hline & Minimum & Maximum & Mean & Std. Deviation & N \\
\hline Predicted Value & 0.75 & 4.88 & 1.42 & 0.810 & 33 \\
Std. Predicted Value & -0.837 & 4.268 & 0.000 & 1.000 & 33 \\
Standard Error of Predicted Value & 0.082 & 0.191 & 0.117 & 0.026 & 33 \\
Adjusted Predicted Value & 0.67 & 4.46 & 1.41 & 0.764 & 33 \\
Residual & -0.413 & 0.264 & 0.000 & 0.184 & 33 \\
Std. Residual & -1.899 & 1.214 & 0.000 & 0.848 & 33 \\
Stud. Residual & -2.303 & 1.402 & 0.013 & 1.014 & 33 \\
Deleted Residual & -0.607 & .538 & 0.010 & 0.273 & 33 \\
Stud. Deleted Residual & -2.568 & 1.434 & -0.001 & 1.055 & 33 \\
Mahal. Distance & $\mathbf{3 . 5 7 6}$ & $\mathbf{2 3 . 8 4 6}$ & $\mathbf{8 . 7 2 7}$ & $\mathbf{4 . 6 7 8}$ & 33 \\
Cook's Distance & $\mathbf{0 . 0 0 0}$ & $\mathbf{0 . 4 7 5}$ & $\mathbf{0 . 0 5 4}$ & $\mathbf{0 . 0 9 7}$ & 33 \\
Centered Leverage Value & 0.112 & 0.745 & 0.273 & 0.146 & 33 \\
\hline
\end{tabular}

${ }^{a}$ Dependent Variable: My organization adopts a Corporate Social Responsibility strategy [S2_Q6].

Histogram

Dependent Variable: My organization adopts a Corporate Social Responsibility strategy

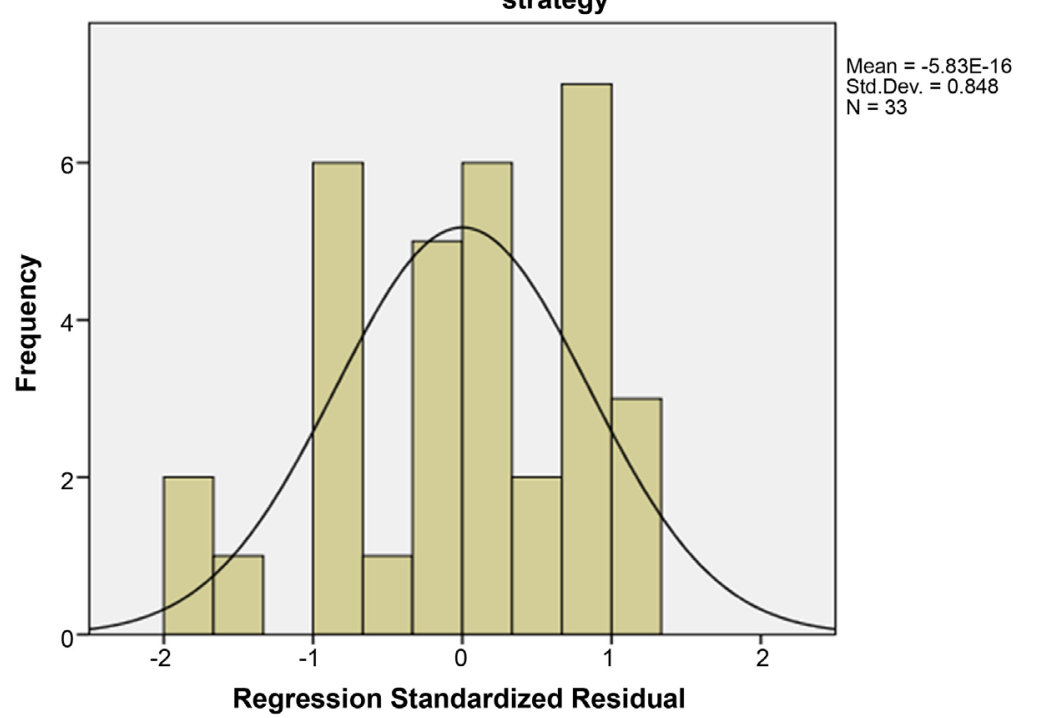

Figure 3. Standardized residual histogram. 
the Standardized Residual Histogram shows a normal distribution behavior, based on the idea that the $\mathrm{z}$-scores of individual studies, also known as standardized residuals, are expected to follow a normal distribution around the combined effect size [74] (p. 41).

In addition to the aforementioned, the Breusch-Pagan and Koenker tests determine whether or not the residuals of the regression exhibit heteroskedasticity [71] (p. 483). Also, according to Daryanto (2018) [75], the Breusch-Pagan test is a large sample test and assumes the residuals to be normally distributed. To run these tests, the authors imported an Ahmad Daryanto's (2018) [75] Heterskedasticity extension to SPSS version 23 software. Running these tests, the following outcomes resulted:

1) Ordinary Least Squares (OLS) analysis matrix is obtained which is similar to the results reported in Tables 9-11.

Original Regression model: Dependent variable: S2_Q6

R-square $=0.951$

OLS outputs

\begin{tabular}{ccccccc}
\hline & $\mathbf{b}$ & $\mathbf{s e}$ & $\mathbf{t}$ & $\mathrm{Sig}$ & $95 \% \mathrm{LB}$ & 95\%UB \\
\hline constant & -0.686 & 0.218 & -3.151 & 0.004 & -1.113 & -0.259 \\
S2_Q2 & 0.642 & 0.048 & 13.329 & 0.000 & 0.548 & 0.737 \\
S3_Q7B & -0.409 & 0.097 & -4.235 & 0.000 & -0.599 & -0.220 \\
S1_Q5B & -0.433 & 0.096 & -4.516 & 0.000 & -0.621 & -0.245 \\
S1_Q5D & 0.346 & 0.100 & 3.473 & 0.002 & 0.151 & 0.542 \\
S1_Q5C & 0.492 & 0.097 & 5.049 & 0.000 & 0.301 & 0.683 \\
S1_Q3 & 0.680 & 0.180 & 3.786 & 0.001 & 0.328 & 1.032 \\
S1_Q7B & 0.488 & 0.125 & 3.911 & 0.001 & 0.244 & 0.733 \\
S1_Q7G & -0.792 & 0.123 & -6.440 & 0.000 & -1.033 & -0.551 \\
S2_Q4 & 0.174 & 0.059 & 2.923 & 0.008 & 0.057 & 0.290 \\
\hline
\end{tabular}

2) OLS outputs with heterocedasticity-robust standard errors (se):

\begin{tabular}{ccccccc}
\hline & b & se & t & Sig & 95\%LB & 95\%UB \\
\hline constant & -0.686 & 0.150 & -4.587 & 0.000 & -1.113 & -0.259 \\
S2_Q2 & 0.642 & 0.094 & 6.849 & 0.000 & 0.548 & 0.737 \\
S3_Q7B & -0.409 & 0.124 & -3.307 & 0.003 & -0.599 & -0.220 \\
S1_Q5B & -0.433 & 0.125 & -3.454 & 0.002 & -0.621 & -0.245 \\
S1_Q5D & 0.346 & 0.110 & 3.142 & 0.005 & 0.151 & 0.542 \\
S1_Q5C & 0.492 & 0.114 & 4.300 & 0.000 & 0.301 & 0.683 \\
S1_Q3 & 0.680 & 0.122 & 5.560 & 0.000 & 0.328 & 1.032 \\
S1_Q7B & 0.488 & 0.210 & 2.329 & 0.029 & 0.244 & .733 \\
S1_Q7G & -0.792 & 0.206 & -3.843 & 0.001 & -1.033 & -0.551 \\
S2_Q4 & 0.174 & 0.063 & 2.772 & 0.011 & 0.057 & 0.290
\end{tabular}

*Note: standard error is HC3 variant. 


\begin{tabular}{cccccc}
\hline \multicolumn{7}{c}{} & \multicolumn{5}{c}{ - } \\
& SS & df & MS & F & Sig \\
\hline Model & 20.974 & 9.000 & 2.330 & 49.310 & 0.000 \\
Residual & 1.087 & 23.000 & 0.047 & -999.000 & -999.000 \\
\hline
\end{tabular}

\section{3) Breusch-Pagan and Koenker tests}

The tests use the scaled residuals from the original OLS above with no adjustment to standard errors.

\section{OLS outputs}

\begin{tabular}{ccccccc}
\hline & $\mathbf{b}$ & se & $\mathbf{t}$ & sig & 95\%LB & 95\%UB \\
\hline constant & 1.031 & 1.270 & 0.812 & 0.425 & -1.458 & 3.520 \\
S2_Q2 & 0.124 & 0.281 & 0.441 & 0.664 & -.427 & 0.674 \\
S3_Q7B & 1.148 & 0.564 & 2.038 & 0.053 & 0.044 & 2.253 \\
S1_Q5B & -0.311 & 0.559 & -0.556 & 0.584 & -1.407 & 0.785 \\
S1_Q5D & 0.177 & 0.581 & 0.304 & 0.764 & -0.962 & 1.316 \\
S1_Q5C & 0.050 & 0.568 & 0.087 & 0.931 & -1.064 & 1.163 \\
S1_Q3 & -0.520 & 1.047 & -0.496 & 0.624 & -2.571 & 1.532 \\
S1_Q7B & -0.601 & 0.728 & -0.826 & 0.417 & -2.028 & 0.826 \\
S1_Q7G & 0.001 & 0.717 & 0.002 & 0.998 & -1.403 & 1.406 \\
S2_Q4 & -0.057 & 0.347 & -0.165 & 0.871 & -0.736 & 0.622 \\
\hline
\end{tabular}

R-square $=0.292$

\begin{tabular}{cccccc}
\hline \multicolumn{5}{c}{} & \multicolumn{7}{c}{----ANOVA TABLE------ } & \\
\hline & SS & df & MS & F & Sig \\
\hline Model & 15.229 & 9.000 & 1.692 & 1.054 & 0.000 \\
Residual & 36.940 & 23.000 & 1.606 & -999.000 & -999.000
\end{tabular}

Breusch-Pagan (BP) and Koenker test statistics and sig-values

\begin{tabular}{ccc}
\hline Lagrangian multiplier. & (LM) & Sig \\
\hline BP & 7.614 & 0.573 \\
Koenker & 9.633 & 0.381 \\
\hline
\end{tabular}

Null hypothesis: heteroskedasticity not present (homoskedasticity).

If sig-value is less than 0.05 , reject the null hypothesis. In this case Sig $\mathrm{P}>\alpha=$ $5 \%$, therefore accepting the Null hypothesis and heteroskedasticity is not present. Therefore, the variance of the errors from the regression is not dependent on the values of the independent variables.

Worth mentioning that Hayes (2017, October 8) [76], created a heteroskedasticity consistent standard error estimator and made it available to the public. The researchers imported an Andrew Hayes's (2017) RLM macro (v1.01, updated 8 Oct 2017) used in his book, as an extension to SPSS version 23 software. Run- 
ning this test, standardized regression coefficients (stand betas) were obtained with $95 \%$ confidentiality level and taking heteroskedasticity in account. The aforementioned coefficients were similar to those reported in Table 9.

\subsection{Reliability}

The Internal Reliability of the 14-item scale is assessed using the Cronbach's Alpha technique. Table 13 shows that the 14-item scale produced a Cronbach's Alpha $=0.822$, in addition that Cronbach's alpha if items deleted all fall in the range 0.795 to 0.895 matching the range 0.8 - 0.9 labeled "Very Good" ([71] (p. 57), [77] (p. 481). This indicates a very good strength of association and proves that the selection of the questions is suitable for the questionnaire purpose.

\section{Conclusions and Recommendations}

Although it has been a while since the civil war ended in Lebanon, Lebanon is still officially going through a process of reconstruction which has been facing a lot of obstacles because of corrupt and unethical practices in both the private and public sectors. However, we noticed recently an increase in awareness from the public to the positive impacts of CSR on the economy as a whole. They realize that there is a direct relationship between good corporate governance, transparency, and increase in CSR of corporations on the society [4].

\subsection{Conclusions}

This paper focuses on the assessment of what motivates companies in Lebanon to adopt CSR strategies. It also highlights people's awareness about CSR which in turn forces these companies to engage in CSR activities that will lead to a win-win situation.

Results have shown that $70.6 \%$ are acquainted with CSR and corresponding activities in Lebanon, a number that is almost similar to that obtained by Hejase et al. (2017) [3] who found that $74.3 \%$ of their 200 respondents are "aware of CSR activities and agree on the fact that CSR is beneficial to society, corporations, and individuals" (p. 16). Also, 78.4\% of the respondents believe that organizations which practice CSR affect their image and such image helps attract job seekers. The aforementioned result is an improvement when compared to that by Hejase et al. (2012a) [33] which showed that " $41 \%$ of the respondents expect that CSR will produce positive outcomes by enhancing the corporate image and reputation" (p. 16). Moreover, this paper's results depict that $54 \%$ of the respondents ask for the organizations' CSR practices in their pursuit of a job, and almost $70 \%$ of the respondents felt motivated to apply for the job due to the organizations' CSR practices.

Table 13. Reliability statistics.

\begin{tabular}{cc}
\hline Cronbach's Alpha & N of Items \\
\hline 0.822 & 14
\end{tabular}


Furthermore, on the average $73.3 \%$ of the respondents demonstrated a positive attitude towards their organization's CSR practices, where they agreed that their companies have a CSR strategy; encourage employees to participate in local community activities; give regular financial support to local community activities and projects; communicate their values to customers, business partners, suppliers and other stakeholders; adopt a Corporate Social Responsibility strategy; and finally assess the impact of their business on the stakeholders. The aforementioned fits Nielsen's (2013) [78] observation who posits that, "social consciousness is a growing factor... and that the share of consumers interested in companies that have implemented programs to give back to society is growing" (p. 11).

CSR as a concept and as a practice in Lebanon is dependent on the level and situation of Corporate Governance. In Lebanon it is inevitable that the issue will continue to rise in importance as a need and as a recognized potential within private sector decision makers and corporate consultants. This research found that the majority of the respondents agreed about most of the motivators which incentivize their organizations to adopt a CSR strategy (Table 4) including top management ethical motivation, improved corporate image, commercial advantages, increased efficiency, employees' satisfaction, external pressures, and public incentives. The overall average of importance of the aforementioned factors is $74 \%$ which is acceptable.

Further results from this research show the readiness of the respondents' Lebanese institutions to embark in a broad selection of CSR activities. $76.47 \%$ of the respondent agreed that the implementation of CSR should be the responsibility of every company; that governments should reward companies that adopt CSR (79.4\%); and companies should allocate a CSR budget (76.5\%). However, when respondents were asked about the CSR activities which their organizations are involved, they agreed that the three highest scored actions are related to reducing environmental impact, that is, waste recycling, energy saving, and use of renewable resources even though the percentages are not too high, 40-60\%. Followed by selected CSR community actions which are traditional in nature with $48 \%$ opting for donations to organizations having social or environmental utility, $40.2 \%$ opting for sponsoring sports and cultural events, and $31.4 \%$ opting for partnership projects of social solidarity including illiteracy, health, women issues, etc..., among others. It is concluded that charity, environmental, and cultural activities in general carry the highest interest in their minds, a result that fits with findings by other Lebanese researchers ([3] [33] [61]).

Many companies have noticeably changed in the manner to which they communicate to their market by adopting a new language that speaks to the collective thought of Lebanese society. This research showed that employee awareness is positively influenced by social media and newspapers as compared to organizational reports. Many companies also followed the general Lebanese mood. By becoming more sensitive and by quickly adapting and following the current mood, companies are realizing that they function within a community and that 
they should be more sensitive to its need. According to Naoufal (2016) [79], "CSR Lebanon $6^{\text {th }}$ annual convention forum discussed how businesses are looking for various ways to currently integrate social impact programs into their business plans" (Para 2). Furthermore, in this research's questionnaire, question seven in part one asks the respondents if they know any companies that currently practice CSR in Lebanon. Respondents answered by giving examples of most Lebanese banks and some hotels and telecommunication industries, waste management firms, and retail firms. More and more companies are moving toward a trend to adopt CSR and incorporate them in there strategies in the societies where they work in. Naoufal (2016) [79] in her report mentions many different Lebanese institutions seeking CSR active roles like banks, NGOs, the Central Bank of Lebanon, the Association of Banks in Lebanon, educational institutions, the Lebanese Army, Service industry, manufacturing firms, etc...

Finally, respondents were asked if there is an area related to CSR that matters to them and they want to comment about, 48 respondents (47.06\%) brought forward the relationship between CSR and Talent Management as a fundamental aspect of corporations in engaging employees and consequently leading to retention. As a matter of fact, Wellins, Smith, \& Erker (2009) [80] contend that "careful planning, culminating in a sound talent strategy that is tightly connected to the organization's overall business strategies and business needs, is required for talent management to become ingrained in an organization's culture and practices. Only when this happens is it possible for talent management to be both effective and sustainable" (p. 12). Considering the aforementioned fits Toyne's (2005) [30] assertiveness that corporate governance embeds many strategic areas including CSR, in all its dimensions and in particular internal stakeholders like employees. As presented earlier in this paper, HR managers have crucial intervention to the delivery of engagement exercises to employees, including training, to assure an attachment to CSR values, accountability and behavior.

Hejase et al. (2016a) [81] assert that "keeping talent is vital given the effort and investment taken to identify and develop them. People have needs which when organizations deal with, makes the working conditions attractive" (p.516). Therefore, "effective leaders are to have a clear understanding of what drives value in their organizations, what motivates their customers, and how to achieve growth in the future" (p. 517). In fact, Wellins, Smith, \& Erker (2009) [80] contend that "organizations must know that they must have the best talent in order to succeed in the hyper-competitive and increasingly complex global economy. Along with the understanding of the need to hire, develop, and retain talented people, organizations are aware that they must manage talent as a critical resource to achieve the best possible results" (p. 1). They recommend that-careful planning, culminating in a sound talent strategy that is tightly connected to the organization's overall business strategies and business needs, is required for talent management to become ingrained in an organization's culture and practice\| (p. 10). Only then talent management is effective and sustainable [82] (p. 115). 
The aforementioned is operationalized by the HR department. The HR Department creates value for those organizations adopting a strategic stance in CSR, by coming up with effective human resource related solutions and creative ideas for dealing with and retaining the right talent [83]. This way, organizations add value to its internal stakeholders who in turn add value to external stakeholders as active believers in their own social endeavors.

Having an integrated Corporate Governance, CSR, and Talent Management leads to increase quality of human capital, employees performance, social engagement, reputation, and financial returns ([4] [30] [40] [47] [55] [83]).

\subsection{Recommendations}

It is clear from the results that the Lebanese organizations are putting efforts in implementing CSR, they are somewhat moving towards CSR in slightly paced steps. They should integrate CSR more in their daily operations to meet the employees and people's expectations. However, Lebanese corporations that are applying a CSR strategy or revisiting their current CSR strategy must do that following a scientific, structured and realistic approach by carrying out an extensive CSR situation analysis to "clearly assess the current status of their activities dedicated to achieve their financial viability amid the concern for the well-being of their stakeholders (externally and internally) and the justification of their choice of actions" [3] (p. 17). Special emphasis to the aforementioned is that CSR is not a mere manipulation tool [84] (p. 195) or a marketing public relations approach [85] (p. 23), it is a proven concept that has sustainability impact for businesses ([6] (pp. 10-12), [40] (p. 39), [69] (p. 1547)).

Hence, an awareness campaign on CSR targeting the private and public sector is needed and is essential to improve the state of CSR in Lebanon even though Lebanese companies are willing to go through with CSR but they need some kind of push and incentives and an awareness campaign might be the right start. Here, it is worth mentioning that several NGOs are leading such an initiative in partnerships with different Lebanese economic sectors [79].

Though, on the other hand, in this research, it is noticed from the results of the survey that people under the age of 25 years old have little to no knowledge about CSR. This means that universities should seriously think of planting specialized CSR educational material and promote on campus activities to introduce the CSR topic to all of its students to create awareness among the new generations. Universities, in this case, activate and strengthen their strategic initiatives to build and extend their services to the community by teaching and engaging students about the importance and significance of CSR to their community and the environment. According to Nejati, Shafaei, Salamzadeh and Daraei (2011) [86], "Universities are no longer just institutions of higher education and research, which grants academic degrees in a variety of subjects, but rather they are turning into institutions ... which train responsible humans, create cutting-edge knowledge to solve the issues and problems at a global scale and share 
the knowledge so that it can benefit the community" (p. 445).

As for the Human Capital dimension and CSR, according to Hejase, Eid, Hamdar, and Haddad (2012b) [87], "many Lebanese companies failed to identify their employees' talents; they should start considering anyone working for their company as a talent and should invest in it" (p. 31). Therefore, and as Hejase, Rifai, Tabsh, and Hejase (2012c) [88] contend, "it is urgently recommended that strategically integrated human capital programs like talent management are to be adopted to capitalize on the new generation of better prepared future employees" (p. 37). Consequently, and according to Hejase et al. (2016b) [83], "organizations have to get interested in developing their human capital by developing their employees' knowledge, applied experience, enterprise processes, customer relationships, and professional skills" (p. 571). Furthermore, the company's culture should be adaptable to all the employees as this will strengthen the common view towards the vision of the company [83] (p. 594).

\subsection{Research Attributes}

This research offers many attributes as supported by the following facts: 1) the parametric assessment of organization adoption of strategic CSR stance and identified explanatory factors at work in a Middle Eastern country like Lebanon; 2) Its contribution to fill the gaps in the reported body of knowledge of CSR's strategic stance versus the triple bottom line factors and more importantly organizational need for talent to cope with such concept at the workplace, and 3) It presents an opportunity for other researchers to expand the scope of the current work, for this topic can be studied on a wider scope and deeper level if CSR stances were to be measured from the point of view of board of directors (BODs).

\subsection{Limitations}

This research has certain limitations including the sample size and the choice of judgmental or convenience sampling of the respondents. Also, respondents are chosen based on selection bias, for the selected individuals belong to specific firms and companies. Consequently, the reader and the researcher must not generalize the findings, even though these findings are labeled primary data and therefore fundamental to the exploratory research presented herein.

\subsection{Future Research}

As CSR is becoming a more vital concept in all societies and after admitting that organizations and firms can't work in an environment without giving back to it in a moral and ethical way, future research might be conducted on a broader range including more companies and universities in its survey in order to generalize more the findings of this study and thus making it more reliable and valid.

\section{Acknowledgements}

The authors would like to acknowledge the constructive criticism and editing 
performed by Prof. Hussin J. Hejase, Dean of the Faculty of Business Administration at Al Maaref University, Beirut, Lebanon.

\section{Conflicts of Interest}

The authors declare no conflicts of interest regarding the publication of this paper.

\section{References}

[1] Pohle, G. and Hittner, J. (2008) Attaining Sustainable Growth through Corporate Social Responsibility. IBM Institute for Business Value, New York.

[2] Jones, G.R. and George, J.M. (2009) Contemporary Management. 6th Edition, McGraw Hill, New York, 135-140.

[3] Hejase, H.J., Hashem, F., Al Dirani, A., Haddad, Z. and Atwi, K. (2017) Corporate Social Responsibility Impact on Consumer Decision. The Journal of Middle East and North Africa Sciences, 3, 3-20. https://doi.org/10.12816/0034675

[4] Macaron, L.F. (2019) Impact of CSR Activities on Organizational Identification (OI) and Job Satisfaction (JS) in Lebanese Commercial Banks. International Journal of Advanced Engineering, Management and Science, 5, 35-47. https://doi.org/10.22161/ijaems.5.1.6

[5] Boafo, N.D. and Kokuma, D.A. (2016) The Impact of Corporate Social Responsibility on Organisational Performance: A Case Study of Vodafone Ghana Limited. $\mathrm{Eu}-$ ropean Journal of Business and Management, 8, 46-57.

[6] Hohnen, P. (2007) Corporate Social Responsibility: An Implementation Guide for Business. http://www.iisd.org/pdf/2007/csr_guide.pdf

[7] Golob, U., Lah, M. and Jancic, Z. (2008) Value Orientations and Consumer Expectations of Corporate Social Responsibility. Journal of Marketing Communications, 14, 83-96. https://doi.org/10.1080/13527260701856525

[8] D'Amato, A., Henderson, S. and Florence, S. (2009) Corporate Social Responsibility and Sustainable Business. A Guide to Leadership Tasks and Functions. Center for Creative Leadership, Greensboro.

[9] European Commission (2002) Corporate Social Responsibility: A Business Contribution to Sustainable Development. Brussels.

https://ec.europa.eu/europeaid/sites/devco/files/communication-corporate-social-re sponsibility-sustainable-development-com2002347-20020702_en.pdf

[10] Carroll, A.B. (1999) Corporate Social Responsibility Evolution of a Definitional Construct. Business \& Society, 38, 268-295.

https://doi.org/10.1177/000765039903800303

[11] Moir, L. (2001) What Do We Mean by Corporate Social Responsibility? Corporate Governance: International Journal of Business and Society, 1, 16-22.

https://doi.org/10.1108/EUM0000000005486

[12] Joyner, B.E. and Payne, D. (2002) Evolution and Implementation: A Study of Values, Business Ethics and Corporate Social Responsibility. Journal of Business Ethics, 41, 297-311. https://doi.org/10.1023/A:1021237420663

[13] Carter, C.R. and Jennings, M.M. (2004) The Role of Purchasing in Corporate Social Responsibility: A Structural Equation Analysis. Journal of Business Logistics, 25, 145-186. https://doi.org/10.1002/j.2158-1592.2004.tb00173.x

[14] O’Dwyer, B. (2002) Managerial Perceptions of Corporate Social Disclosure. Ac- 
counting, Auditing \& Accountability Journal, 15, 406-436. https://doi.org/10.1108/09513570210435898

[15] Johnston, K. and Beatson, A. (2005) Managerial Conceptualization of Corporate Social Responsibility: An Exploratory Study. Proceedings Australia New Zealand Marketing Academy Conference, Perth, 1-7. http://eprints.qut.edu.au/9857/1/9857.pdf

[16] Dahlsrud, A. (2008) How Corporate Social Responsibility Is Defined: An Analysis of 37 Definitions. Corporate Social Responsibility and Environmental Management, 15, 1-13. https://doi.org/10.1002/csr.132

[17] Montiel, I. (2008) Corporate Social Responsibility and Corporate Sustainability: Separate Pasts, Common Futures. Organization and Environment, 21, 245-269. https://doi.org/10.1177/1086026608321329

[18] Taneja, S.S., Taneja, P.K. and Gupta, R.K. (2011) Researches in Corporate Social Responsibility: A Review of Shifting Focus, Paradigms, and Methodologies. Journal of Business Ethics, 101, 343-364. https://doi.org/10.1007/s10551-010-0732-6

[19] Goebbels, M. (2002) Reframing Corporate Social Responsibility: The Contemporary Conception of a Fuzzy Notion. Journal of Business Ethics, 44, 95-105.

[20] Van Marrewijk, M. (2003) Concepts and Definitions of CSR and Corporate Sustainability: Between Agency and Communion. Journal of Business Ethics, 44, 95-105. https://doi.org/10.1023/A:1023331212247

[21] Matten, D. and Crane, A. (2005) Corporate Citizenship: Towards an Extended Theoretical Conceptualization, The Academy of Management Review, 30, 166-179. https://doi.org/10.5465/amr.2005.15281448

[22] Gond, J.-P. and Crane, A. (2010) Corporate Social Performance Disoriented: Saving the Lost Paradigm? Business \& Society, 49, 677-703.

https://doi.org/10.1177/0007650308315510

[23] European Commission (2001) Promoting a European Framework for Corporate Social Responsibility-Green Paper. Office for Official Publications of the European Commission, Luxembourg.

[24] Werther, W.B. and Chandler Jr., D. (2011) Strategic Corporate Social Responsibility: Stakeholders in a Global Environment. Sage Publications, Thousand Oaks.

[25] Schwartz, M. and Carroll, A. (2003) Corporate Social Responsibility: A Three-Domain Approach. Business Ethics Quarterly, 13, 503-530. https://doi.org/10.5840/beq200313435

[26] International Labour Office (2006) Resource Guide on Corporate Social Responsibility (CSR). GB.295/MNE/2/1-295th Session. https://www.ilo.org/public/libdoc/ilo/GB/295/GB.295_MNE_2_1_engl.pdf

[27] European Commission (2011) A Renewed EU Strategy 2011-14 for Corporate Social Responsibility. Brussels.

http://www.europarl.europa.eu/meetdocs/2009_2014/documents/com/com_com(20 11)0681_/com_com(2011)0681_en.pdf

[28] The World Business Council for Sustainable Development (2012) The Business Case for Sustainable Development: Making a Difference. 6. http://www.wbcsd.org/web/publications/business-case.pdf

[29] Hys, K. and Hawrysz, L. (2012) Corporate Social Responsibility Reporting. China-USA Business Review, 11, 1515-1524.

https://doi.org/10.17265/1537-1514/2012.11.009

https://www.researchgate.net/publication/268925189_Corporate_Social_Responsibi 
lity_Reporting

[30] Toyne, P. (2005) CSR-An Introduction. https://www.management-issues.com/opinion/1944/csr-an-introduction

[31] Business for Social Responsibility (BSR) (2013) A New CSR Frontier: Business and Population Health. https://www.bsr.org/reports/BSR_A_New_CSR_Frontier_Business_and_Population _Health.pdf

[32] Minolta, K. (2018) CSR Report 2018. https://www.konicaminolta.eu/getmedia/13d55a16-712f-42bc-9314-33078f226cfa/K M-CSR-Report-2018.pdf.aspx

[33] Hejase, H., Farha, C., Haddad, Z. and Hamdar, B. (2012) Exploring the Multiple Benefits of CSR on Organizational Performance: Case of Lebanon. Journal of Social Sciences, 1, 1-23.

[34] CSR Lebanon (2019) About Us: Mission. http://www.csrlebanon.com/Home/About-Us

[35] Kotler, P. and Lee, N. (2005) Corporate Social Responsibility: Doing the Most Good for Your Company and your Cause. Wiley, Hoboken.

[36] International Institute for Sustainable Development (2013) Corporate Social Responsibility (CSR). https://www.iisd.org/business/issues/sr.aspx

[37] CSR Middle East (2013) Forum to Promote CSR in Lebanon. http://csrmiddleeast.org/profiles/blogs/forum-to-promote-csr-in-lebanon

[38] Carroll, A.B. (1979) A Three-Dimensional Conceptual Model of Corporate Social Performance. Academy of Management Review, 4, 497-505. https://doi.org/10.5465/amr.1979.4498296

[39] Katsoulakos, P., Koutsodimou, M., Matraga, A. and Williams, L. (2004) A Historical Perspective of the CSR Movement, CSR Quest Sustainability Framework. https://www.researchgate.net/publication/309418756_Exploring_the_Drivers_and_ Nature_of_Corporate_Social_Responsibility_from_an_African_Perspective

[40] Carroll, A.B. (2008) A History of Corporate Social Responsibility. In: Crane, A., McWilliams, A., Matten, D., Moon, J. and Siegel, D., Eds., the Oxford Handbook of Corporate Social Responsibility, Oxford University Press, Oxford, 39. https://doi.org/10.1093/oxfordhb/9780199211593.003.0002

[41] Teach, E. (2005) Two Views of Virtue. CFO, 31-34.

[42] Lydenberg, S.D. (2005) Corporations and the Public Interest: Guiding the Invisible Hand. Berrett-Koehler Publishers, San Francisco.

[43] Vogel, D. (2006) The Market for Virtue: The Potential and Limits of Corporate Social Responsibility. Brookings Institution Press, Washington DC.

[44] Carroll, A. (2010) CSR in the Future. In: Visser, W., Matten, D., Pohl, M. and Tolhurst, N., Eds., the $A$ to $Z$ of Corporate Social Responsibility, John Wiley \& Sons, Inc., Chichester, 113.

[45] Vaaland, T.I. and Heide, M. (2008) Managing Corporate Social Responsibility: Lessons from the Oil Industry. Corporate Communications. An International Journal, 13, 212-225. https://doi.org/10.1108/13563280810869622

[46] Hartmann, M. (2011) Corporate Social Responsibility in the Food Sector. European Review of Agricultural Economics, 38, 297-324. https://doi.org/10.1093/erae/jbr031

[47] Brammer, S., Jackson, G. and Matten, D. (2012) Corporate Social Responsibility and Institutional Theory: New Perspectives on Private Governance. Socio-Economic 
Review, 10, 3-28. https://doi.org/10.1093/ser/mwr030

[48] Isaksson, R. and Steimle, U. (2009) What Does GRI Reporting Tell Us about Corporate Sustainability? The TQM Journal, 21, 168-181.

http://www.ep.liu.se/ecp/033/004/ecp0803304.pdf https://doi.org/10.1108/17542730910938155

[49] International Institute for Sustainable Development (2012) Corporate Social Responsibility (CSR). http://www.iisd.org/business/issues/sr.aspx

[50] Industry Canada (2011) Corporate Social Responsibility. http://www.ic.gc.ca/eic/site/csr-rse.nsf/eng/home

[51] Collaborating Centre on Sustainable Consumption and Production (2012) CSR-Kommunikation im Wandel: Status quo und Trends aus Sicht der Unternehmen.

https://www.scp-centre.org/wp-content/uploads/2016/05/78_CSR_Communication =Report_120613.pdf

[52] Collaborating Centre on Sustainable Consumption and Production (2019) CSR Communication in Transformation: Status quo and future trends from a business angle.

https://www.scp-centre.org/publications/csr-communication-in-transformation-sta tus-quo-and-future-trends-from-a-business-angle

[53] Kuttner, M. and Feldbauer-Durstmüller, B. (2018) Corporate Social Responsibility in Family Firms-Status Quo and Future Directions. International Journal of Business Strategy, 18, 47-68. https://doi.org/10.18374/IJBS-18-1.6

[54] Shukla, A. and Challare, N. (2019) Corporate Social Responsibility: Status Quo Review. International Journal of Social \& Scientific Research, India, 1, 28-31.

[55] Gildan Genuine Responsibility (2017) 2017 Sustainability Report. https://www.genuineresponsibility.com/media/uploads/reports/2017_corporatesoci alresponsibilityreport_en_ZyXVtpK.pdf

[56] Arshad, I.S., Muhammad, T. and Al Astal, A.Y.M. (2015) Empirical Study on Corporate Social Responsibility in United Arab Emirates. International Journal of Scientific and Research Publication, 5, 1-5.

[57] Jahamani, Y. (2003) Green Accounting in Developing Countries: The Case of U.A.E. and Jordan. Managerial Finance, 29, 37-45. https://doi.org/10.1108/03074350310768418

[58] Kamla, R. (2007) Critically Appreciating Social Accounting and Reporting in the Arab Middle East: A Postcolonial Perspective. Advances in International Accounting, 20, 105-177. https://doi.org/10.1016/S0897-3660(07)20005-4

[59] Katsioloudes, M.I. and Brodtkorb, Y. (2007) Corporate Social Responsibility: An Exploratory Study in the United Arab Emirates. SAM Advanced Management Journal, 72, 9-20.

[60] Rettab, B., Ben Brik, A. and Mellahi, K. (2009) A Study of Management Perceptions of the Impact of Corporate Social Responsibility on Organisational Performance in Emerging Economies: The Case of Dubai. Journal of Business Ethics, 89, 371-390. https://doi.org/10.1007/s10551-008-0005-9

[61] Jamali, D., Sidani, Y. and El-Asmar, K. (2009) A Three-Country Comparative Analysis of Managerial CSR Perspectives: Insights from Lebanon, Syria, and Jordan. Journal of Business Ethics, 85, 173-192. https://doi.org/10.1007/s10551-008-9755-7

[62] Hossain, M. and Hammami, H. (2009) Voluntary Disclosure in the Annual Reports of an Emerging Country: The Case of Qatar. Advances in Accounting, 25, 255-265. 
https://doi.org/10.1016/j.adiac.2009.08.002

[63] Abu Farha, E. and Alkhalaileh, M. (2016) The Relationship between Corporate Social Responsibility's Disclosure and Financial Performance: An Empirical Study of Jordanian Companies Listed on Amman Stock Exchange. Jordan Journal of Business Administration, 12, 401-415. https://doi.org/10.12816/0033356

[64] McWilliams, A., Siegel, D.S. and Wright, P.M. (2006) Corporate Social Responsibility: International Perspectives. https://doi.org/10.2139/ssrn.900834

[65] Chandler, D. and Werther Jr., W.B. (2013) Strategic Corporate Social Responsibility: Stakeholders, Globalization, and Sustainable Value Creation. 3rd Edition, SAGE Publications, Thousand Oaks.

[66] Light, P. (2008) Search for Social Entrepreneurship. Brookings Institution Press, Washington DC.

[67] Silva Niño, A.C. (2015) Social Entrepreneurship and Corporate Social Responsibility: Differences and Points in Common. Journal of Business \& Economic Policy, 2, 85-93.

[68] Kaufman, S. (2016) Corporate Social Responsibility Can Give Entrepreneurs an Edge. https://www.entrepreneur.com/article/281817

[69] Szegedi, K., Fülöp, G. and Bereczk, Á. (2016) Relationships between Social Entrepreneurship, CSR and Social Innovation: In Theory and Practice. International Journal of Economics and Management Engineering, 10, 1543-1548.

[70] Asemah, E.S., Okpanachi, R.A. and Edegoh, L.O.N. (2013) Business Advantages of Corporate Social Responsibility Practice: A Critical Review. New Media and Mass Communication, 18, 45-54.

[71] Hejase, A.J. and Hejase, H.J. (2013) Research Methods: A Practical Approach for Business Students. 2nd Edition, Massadir Inc., Philadelphia.

[72] Yamane, T. (1967) Statistics: An Introductory Analysis. 2nd Edition, Harper and Row, New York.

[73] Hecht, B., Nielsen, K.U. and Sadlovska, V. (2015) 2015 Global CSR RepTrak 100. Reputation Institute, Boston.

https://www.rankingthebrands.com/PDF/CSR\%20Global\%20RepTrak\%202015,\%20 Reputation\%20Institute.pdf

[74] Sutton, A.J., Abrams, K.R., Jones, D.R., Jones, D.R., Sheldon, T.A. and Song, F. (2000) Methods for Meta-Analysis in Medical Research. John Wiley \& Sons Inc., Chichester.

[75] Daryanto, A. (2018) Heteroskedasticity_test_daryanto_V2b.spd (5k). https://sites.google.com/site/ahmaddaryanto/scripts/Heterogeneity-test

[76] Hayes, A.F. (2017) RALM.ZIP Archive Containing the Data Files Used in the Book, the RLM Macro (v1.01, Updated 8 Oct. 2017).

http://afhayes.com/regression-analysis-and-linear-models.html

[77] Burns, R. and Burns, R. (2008) Cluster Analysis. In: Business Research Methods and Statistics Using SPSS, Sage Publications, Thousand Oaks, 481.

[78] Nielsen (2013) Consumers Who Care: And Say They'll Reward Companies with Their Wallet. The Nielsen Company, New York. https://www.nielsen.com/wp-content/uploads/sites/3/2019/04/Nielsen-Global-Repo rt-Consumers-Who-Care-August-2013.pdf

[79] Naoufal, P. (2016) CSR: A Growing Trend in Lebanon's Banks, Businesses and Schools. 
https://en.annahar.com/article/491727-corporate-social-responsibility-growing-win g-in-importance-for-lebanons-business

[80] Wellins, R.S., Smith, A.B. and Erker, S. (2009) Nine Best Practices for Effective Talent Management. White Paper, Development Dimensions International, Inc., Bridgeville.

http://www.ddiworld.com/DDI/media/white-papers/ninebestpracticetalentmanage ment_wp_ddi.pdf?ext=.pdf

[81] Hejase, H.J., Hejase, A.J., Mikdashi, G. and Farhat Bazeih, Z. (2016) Talent Management Challenges: An Exploratory Assessment from Lebanon. International Journal of Business Management and Economic Research, 7, 504-520.

[82] Hejase, H.J., Hamdar, B., Haddad, Z., Chaaya, M., Hejase, A.J. and Beyrouti, N. (2014) Corporate Entrepreneurship in Lebanon: An Exploratory Research. Quarterly Journal of Business Studies, 1, 94-118.

[83] Hejase, H.J., Hejase, A.J., Tabch Assi, H. and Chalak, H.C. (2016b) Intellectual Capital: An Exploratory Study from Lebanon. Open Journal of Business and Management, 4, 571-605. https://doi.org/10.4236/ojbm.2016.44061

[84] Kanakriyah, R. (2016) Social Responsibility and Its Effect on the Companies' Success According to Users Opinions in Jordan. International Journal of Economics and Finance, 8, 187-201. https://doi.org/10.5539/ijef.v8n12p187

[85] Arif, A. (2017) Corporate Social Responsıbility: Marketing Tool or a Philanthropic Approach. Journal of Marketing Theory and Applications, 3, 21-39.

[86] Nejati, M., Shafaei, A., Salamzadeh, Y. and Daraei, M. (2011) Corporate Social Responsibility and Universities: A Study of Top 10 World Universities' Websites. African Journal of Business Management, 5, 440-447. http://www.academicjournals.org/AJBM

[87] Hejase, H.J., Eid, A., Hamdar, B. and Haddad, Z. (2012) Talent Management: An Assessment of Lebanese Employees' Knowledge. Universal Journal of Management and Social Sciences, 2, 21-38. https://doi.org/10.1108/00251741011014481

[88] Hejase, H.J., Rifai, R., Tabsh, H. and Hejase, A.J. (2012c) Major Forces Leading to the Shift in the HR Function in Lebanon: An Exploratory Research. British Journal of Humanities and Social Sciences, 7, 21-39. 